\title{
Glucose-induced repression of PPAR $\alpha$ gene expression in pancreatic $\beta$-cells involves PP2A activation and AMPK inactivation
}

\author{
Kim Ravnskjaer, Michael Boergesen, Louise T Dalgaard ${ }^{1}$ and Susanne Mandrup \\ Department of Biochemistry and Molecular Biology, University of Southern Denmark, Campusvej 55, 5230 Odense M, Denmark \\ ${ }^{1}$ Department of Medical Biochemistry and Genetics, University of Copenhagen, 2200 Copenhagen N, Denmark. \\ (Requests for offprints should be addressed to S Mandrup; Email: s.mandrup@bmb.sdu.dk)
}

\begin{abstract}
Tight regulation of fatty acid metabolism in pancreatic $\beta$-cells is important for $\beta$-cell viability and function. Chronic exposure to elevated concentrations of fatty acid is associated with $\beta$-cell lipotoxicity. Glucose is known to repress fatty acid oxidation and hence to augment the toxicity of fatty acids. The peroxisome proliferator activated receptor $\alpha$ (PPAR $\alpha$ ) is a key activator of genes involved in $\beta$-cell fatty acid oxidation, and transcription of the PPAR $\alpha$ gene has been shown to be repressed by increasing concentrations of glucose in $\beta$-cells. However, the mechanism underlying this transcriptional repression by glucose remains unclear. Here we report that glucose-induced repression of PPAR $\alpha$ gene expression in INS-1E cells is independent of $\beta$-cell excitation and insulin secretion but requires activation of protein phosphatase $2 \mathrm{~A}$ in a process involving inactivation of the AMP-activated protein kinase (AMPK). Pharmacological activation of AMPK at high glucose concentrations interferes with glucose repression of PPAR $\alpha$ and PPAR $\alpha$ target genes in INS-1E cells as well as in rat islets. Specific knock-down of the catalytic AMPK-subunit AMPK $\alpha 2$ but not AMPK $\alpha 1$ using RNAi suppressed PPAR $\alpha$ expression, thereby mimicking the effect of glucose. These results indicate that activation of protein phosphatase $2 \mathrm{~A}$ and subsequent inactivation of AMPK is necessary for glucose repression of PPAR $\alpha$ expression in pancreatic $\beta$-cells.
\end{abstract}

Journal of Molecular Endocrinology (2006) 36, 289-299

\section{Introduction}

Tight regulation of $\beta$-cell fatty acid metabolism is important for $\beta$-cell function. Fatty acids acutely potentiate glucose stimulated insulin secretion (Stein et al. 1996, Itoh et al. 2003, Roduit et al. 2004), whereas chronic exposure of $\beta$-cells to elevated concentrations of fatty acids causes $\beta$-cell dysfunction known as lipotoxicity (Shimabukuro et al. 1998b, Maedler et al. 2001). The nuclear receptor peroxisome proliferator activated receptor $\alpha(\mathrm{PPAR} \alpha)$ has previously been shown to be expressed and to activate fatty acid oxidation in pancreatic $\beta$-cells (Zhou et al. 1998). This would bring PPAR $\alpha$ in a position to antagonize lipotoxicity; however, reports on the role of PPAR $\alpha$ in $\beta$-cell function have been conflicting (Guerre-Millo et al. 2001, Tordjman et al. 2002, Gremlich et al. 2004). Recent data from our laboratory showed that acute activation of $\operatorname{PPAR} \alpha$, but not PPAR $\gamma$, has the potential to stimulate mitochondrial $\beta$-oxidation and potentiate glucose-stimulated insulin secretion (GSIS) in both INS-1E insulinoma cells and rat islets (Ravnskjaer et al. 2005). Thus, regulation of PPAR $\alpha$ expression and activity appears essential for adjusting $\beta$-cells to metabolic challenges and for maintenance of $\beta$-cell function.
The lipotoxicity in $\beta$-cells is augmented by hyperglycemia in the pathology of glucolipotoxicity (El Assaad et al. 2003). Glucose interferes with lipid partitioning and redirects the flow from lipid oxidation into lipid accumulation. Instantly, this is accomplished through post-translational modification of numerous metabolic enzymes including acetyl-CoA carboxylase (ACG) (Zhang \& Kim 1995), whereas chronic effects of glucose on lipid metabolism are exerted at the transcriptional level (Roche et al. 1998). Both acute and chronic effects of glucose are antagonized by the AMP-activated protein kinase (AMPK). AMPK is considered a central cellular energy gauge activated by energy depletion, cellular stress and adipokines and is known to promote lipid oxidation (Kahn et al. 2005). Similarly, AMPK shuts down energy-consuming processes such as lipogenesis by suppressing expression and activities of lipogenic enzymes like ACG (Zhang \& Kim 1995) and key lipogenic transcription factors such as sterol regulatory element binding protein 1 (Zhou et al. 2001) and carbohydrate response element binding protein (ChREBP) (Kawaguchi et al. 2002). Inactivation of AMPK by glucose has previously been described in $\beta$-cells and could be a pivotal regulatory event in glucose-induced lipogenesis (Salt et al. 1998b, da Silva 
et al. 2000). In addition to ATP-generation from glucose oxidation, activation of protein phosphatase 2A (or PP2A-like phosphatases) could mediate glucose action through disruption of AMPK subunit interaction (Gimeno-Alcaniz \& Sanz 2003, Samari et al. 2005).

In addition to the activation of lipogenic genes, increasing levels of glucose leads to repression of genes involved in fatty acid oxidation. Pancreatic islets chronically exposed to hyperglycemic conditions show a significant reduction in PPAR $\alpha$ expression level (Zhou et al. 1998, Laybutt et al. 2002), and in vitro studies of insulinoma cells and rat islets confirm this repression by glucose as a direct effect on PPAR $\alpha$ gene transcription (Roduit et al. 2000). However, the molecular mechanism underlying this repression by glucose remains unknown.

Here we report that glucose repression of PPAR $\alpha$ gene expression in pancreatic $\beta$-cells is independent of $\beta$-cell excitation and insulin secretion but involves activation of PP2A (or PP2A-like phosphatase) and acute inactivation of AMPK. Activation of AMPK using the biguanide metformin or the thiazolidinedione (TZD) compound troglitazone completely reverses the glucoseinduced repression of PPAR $\alpha$ and selected PPAR $\alpha$ target genes. Importantly, AMPK activation also abolished glucose repression of the PPAR $\alpha$ gene in isolated rat islets. Similarly, selective inhibition of PP2A activity interferes with the effect of glucose. Specific knock-down of AMPK $\alpha 2$ by shRNA mimics the effect of glucose on the PPAR $\alpha$ expression and supports a model where AMPK activity is necessary to maintain $\beta$-cell PPAR $\alpha$ expression and where AMPK inactivation is instrumental for glucose-induced repression of PPAR $\alpha$ gene expression.

\section{Materials and methods}

\section{Cell culture and glucose stimulation}

The cell line INS-1E was cultured as previously described (Merglen et al. 2004). The cells in use were all at passage numbers between 50 and 70 and used for experiments at $70-80 \%$ confluence. Medium and supplements were from Invitrogen-GIBCO and serum from HyClone. In all glucose experiments, cells were pre-incubated $24 \mathrm{~h}$ in $5 \mathrm{mM}$ glucose media before addition of glucose and compounds. Rat islets were isolated from adult male Wistar rats by collagenase perfusion and pre-cultured for $24 \mathrm{~h}$ in $3 \mathrm{mM}$ glucose medium before addition of glucose and metformin and further incubation for $24 \mathrm{~h}$. Actinomycin D, verapamil and metformin were purchased from Sigma-Aldrich, okadaic acid from Biomol (Plymouth Meeting, PA, USA), and troglitazone was kindly provided by Novo Nordisk (Bagsvaerd, Denmark).

\section{Adenovirus generation and transduction}

pSuper-AMPK $\alpha 1$ and $\alpha 2$ were constructed with specific oligos directed against sequences AGCGGTAGGT AGTCGTTGA and CGCTCGTTGATAGTTTCTG, respectively, as described (Brummelkamp et al. 2002). The H1-promoter and oligos were then excised using SmaI and HindIII and ligated into pShuttle (EcoRV and klenow-filled SalI). Recombinant adenoviruses containing shRNA against AMPK $\alpha 1$ and $\alpha 2$ were generated using the AdEasy cloning system from Stratagene. The linarized plasmids were transfected into 293-HEK cells and the viruses were amplified and purified using $\mathrm{CsCl}$ gradients. Viruses were initially titrated and titers estimated by a plaque assay-based approach. Subsequently, relative titers of functional viruses were equalized based on quantification of the adenoviral transcript AdE4 by real time PCR. Adenoviral vectors expressing simian virus 40 (SV40) small-t antigen and mutated SV40 small-t antigen (C103S) (Porras et al. 1996) were kindly provided by Professor Kathleen Rundell (Feinberg School of Medicine, Chicago). Twenty-four hours after transduction with AdshAMPK $\alpha 1$ or $\alpha 2$, medium was changed to new $5 \mathrm{mM}$ glucose medium and cells were incubated $48 \mathrm{~h}$ before harvest. SV40 Small-t antigen transduction was performed in $5 \mathrm{mM}$ glucose medium and glucose added $24 \mathrm{~h}$ later. All experiments were made at least in duplicate.

\section{Protein analysis by western blotting and ECL detection}

For total protein extraction INS-1E cells were harvested in hypotonic lysis buffer containing SDS. Nuclear extracts were prepared essentially as described in (Roduit et al. 2000). Protein extracts were separated by SDS-PAGE and proteins blotted onto PVDF membranes (Millipore, Billerica, MA, USA) and probed with specific antibodies. Primary antibodies anti-PPAR $\gamma$ (SC-7273) and anti-TFIIB (SC-225) were obtained from Santa Cruz Biotechnology (Santa Cruz, CA, USA) and anti-AMPK $\alpha$ (\#2532) and anti-phosphoAMPK $\alpha$ (Thr172) (\#2531) from Cell Signaling (Danvers, MA, USA). Secondary horseradish peroxidase-coupled antiFc $\gamma$ antibodies, anti-Mouse (P0447) and Anti-Rabbit (P0399), were obtained from DAKO Cytomation (Carpinteria, CA, USA). Densitometric quantification was performed using ImageQuant 5· software from GE Healthcare (Chalfont St. Giles, UK).

\section{RNA isolation and cDNA synthesis}

INS-1E cells were harvested in guadinium thiocyanate, and RNA was isolated according to a modified Chomczynski-Sacchi protocol (Chomczynski \& Sacchi 1987). cDNA was prepared after DNAse treatment (Invitrogen DNAseI) by reverse transcription (Invitrogen 
first-strand-kit) of the isolated RNA primed by random hexamers $(\mathrm{dNTP})_{6}$.

\section{Real time PCR}

Quantitative 3-step real time PCR was performed on the ABI-7700 Prism real time PCR instrument using SyBRgreen master mix (Sigma) and Sigma passive reference according to instructions from the manufacturer. PCR reactions were made in duplicates. Primers for real time PCR were designed using Primer Express 2.0 (Applied Biosystems, Foster City, CA, USA) and specificity and efficacy validated before use. All quantifications were performed with TFIIB as internal standard and presented as fold over control. Primer sequences (forward and reverse, respectively): PPAR $\alpha$ gataccactatggagtccacgca, gccgaaagaagccttgc; TFIIB gtt ctgctccaacctttgcct, tgtgtagctgccatctgcactt; L-PK tggacatc atctttgcctcctt, ctgctaacacgtcactggettt; c-fos cettctccagcatg ggctc, gatctgcgcaaaagtcctgtg acyl-CoA oxidase (ACO) cagataattggcacctacgcc, aagatgagttccgtggccc; carnitine palmitoyl transferase 1 (CPT-1), ctggtgggccacaaattacg, aggtagatatattcttcccaccagtca; AdE4 ctccggaaccaccacag aaa, gcagacatgtttgagagaaaaatgg; SV40 Small-t-Ag tgcagctaatggaccttctaggt, gaatattcccccaggcactc; AMPK $\alpha 1$ aagccaaatcagggactgctac, agtgctgatggatcccgat; AMPK $\alpha 2$ ggcaaagtgaagattggagaaca, aactgccactttatggcctgtc.

\section{Statistical analysis}

Statistical evaluation of the data was performed using the two-tailed Student's $t$-test on paired data or one-way ANOVA (Fig. 5B). Data (relative to control $(5 \mathrm{mM}$ or C)) are presented as means \pm S.D. $(n \geq 3)$ or means \pm range $(n=2)$.

\section{Results}

\section{Glucose represses transcription of the PPAR $\alpha$ gene independently of insulin secretion}

Glucose has previously been reported to repress the expression of PPAR $\alpha$ mRNA in pancreatic $\beta$-cells, and to do so solely at the level of transcription (Roduit et al. 2000). We confirmed this observation in the INS-1E $\beta$-cell line and showed that glucose repression of PPAR $\alpha$ mRNA level is observed within $30 \mathrm{~min}$ (Fig. 1A). In keeping with the notion that this repression occurs at the transcriptional level, inhibition of RNA synthesis with actinomycin $\mathrm{D}$ at $25 \mathrm{mM}$ glucose, did not lead to further reduction in the PPAR $\alpha$ mRNA level (Fig. 1A).

Glucose is known to induce $\beta$-cell excitation, $\mathrm{Ca}^{+2}$ influx and insulin secretion. We therefore wanted to examine if glucose-stimulated $\mathrm{Ca}^{+2}$ influx or GSIS is required for glucose repression of the PPAR $\alpha$ gene in
INS-1E cells. INS-1E cells were pre-incubated with verapamil, a selective $\mathrm{L}$-type $\mathrm{Ca}^{+2}$ channel blocker, prior to 12-h incubation with $25 \mathrm{mM}$ glucose or with the non-nutrient insulin secretagog $\mathrm{KCl}(40 \mathrm{mM})$. Importantly, neither verapamil nor $\mathrm{KCl}$ had any effect on the PPAR $\alpha$ mRNA level (Fig. 1B). This shows that $\mathrm{Ca}^{+2}$ influx and insulin secretion are not implicated in the glucose repression of PPAR $\alpha$ expression. Similarly, neither the specific insulin receptor inhibitor HNMPA$(\mathrm{AM})_{3}$ nor wortmannin affected glucose repression of PPAR $\alpha$ (data not shown). As a control for the experiment, the expression levels of two glucose-induced genes, liver pyruvate kinase (L-PK) and the immediate early gene c-fos, were quantified. In pancreatic $\beta$-cells, L-PK is induced by glucose through activation of the ChREBP independently of $\beta$-cell excitation (Wang \& Wollheim 2002), whereas c-fos induction by glucose is dependent on $\mathrm{Ca}^{+2}$ influx (Susini et al. 1998). As expected, L-PK was induced only by glucose even in the presence of verapamil, while c-fos was induced by both glucose and $\mathrm{KCl}$ in a verapamil sensitive manner (Fig. 1B). Thus, these results show that glucose-induced repression of PPAR $\alpha$ gene expression in INS-1E cells is independent of $\beta$-cell excitation and insulin secretion.

\section{Pharmacological activation of AMPK relieves glucose repression of the PPAR $\alpha$ gene in INS-1E cells and isolated rat islets}

As AMPK activation is known to interfere with glucose induction of gene expression, we wanted to investigate whether activation of AMPK would also counteract the repressive effect of glucose on $\beta$-cell PPAR $\alpha$ expression. INS-1E cells were cultured for $24 \mathrm{~h}$ in medium containing $25 \mathrm{mM}$ glucose in the presence or absence of troglitazone $(5-20 \mu \mathrm{M})$ or metformin $(0 \cdot 25-1 \mathrm{mM})$, both of which have been demonstrated to activate the AMPK in muscle and $\beta$-cells (Fryer et al. 2002, Leclerc et al. 2004). Total RNA was extracted and real time PCR was used to quantify the PPAR $\alpha$ mRNA level relative to that of TFIIB. High concentrations of glucose $(25 \mathrm{mM})$ repressed PPAR $\alpha$ expression to approximately $25 \%$ of the expression at $5 \mathrm{mM}$ glucose $(P<0 \cdot 01)$, whereas increasing concentrations of troglitazone (Fig. 2A) or metformin (Fig. 2B) dose-dependently restored PPAR $\alpha$ expression. We next wanted to see if AMPK activation could also attenuate glucose repression of the PPAR $\alpha$ gene in primary $\beta$-cells. To do so, freshly isolated rat islets were pre-incubated for $24 \mathrm{~h}$ at $3 \mathrm{mM}$ glucose and further incubated for $24 \mathrm{~h}$ at $3 \mathrm{mM}$ or $20 \mathrm{mM}$ glucose, respectively, in the presence or absence of metformin. RNA was extracted and PPAR $\alpha$ levels were quantified by real time PCR and presented relative to TFIIB expression. In line with the effects of AMPK activation in INS-1E cells, metformin completely abolished glucose 

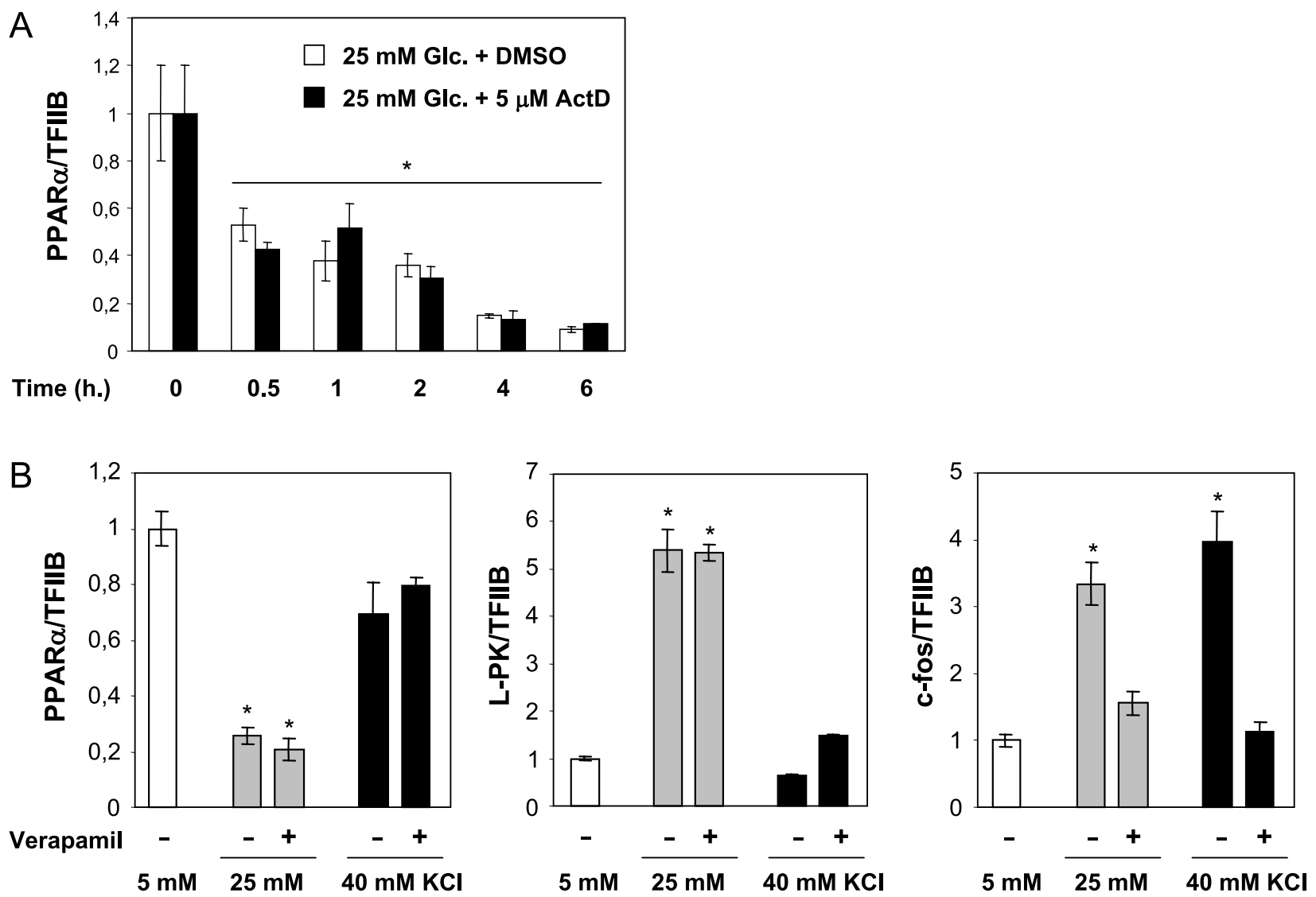

Figure 1 Glucose represses PPAR $\alpha$ mRNA level at the transcriptional level independently of $\beta$-cell excitation or insulin secretion. INS-1E cells were pre-cultured for $24 \mathrm{~h}$ in $5 \mathrm{mM}$ glucose medium before addition of glucose to $25 \mathrm{mM}$ or $40 \mathrm{mM} \mathrm{KCl}$. Where indicated, $5 \mu \mathrm{M}$ actinomycin $\mathrm{D}$ was added together with the glucose or cells were pre-incubated with $20 \mu \mathrm{M}$ verapamil for $1 \mathrm{~h}$ before glucose addition. Cells were subsequently harvested at the indicated time points (A) or after $12 \mathrm{~h}$ incubation (B). Total RNA was extracted and expression of PPAR $\alpha$, L-PK and c-fos were quantified using real time PCR. The data was normalized to TFIIB expression and presented relative to expression at $5 \mathrm{mM}$ glucose. RNA was harvested in duplicates, and range is indicated ( ${ }^{*}$ significantly different from $5 \mathrm{mM}$ glucose $P<0.05$ ). The presented results are representative of at least 3 independent experiments.

repression of PPAR $\alpha$ but had no effect at $3 \mathrm{mM}$ glucose (Fig. 2C). These results indicate that inactivation of AMPK activity is necessary for glucose-induced repression of PPAR $\alpha$ gene expression in pancreatic $\beta$-cells.

\section{AMPK activation by metformin restores PPAR $\alpha$ protein level and expression of PPAR $\alpha$ target genes at high glucose}

To verify that the effects of AMPK activation on PPAR $\alpha$ mRNA level was translated into an increase in PPAR $\alpha$ protein level, nuclear extracts were prepared from INS-1E cells cultured for $24 \mathrm{~h}$ in medium containing $25 \mathrm{mM}$ glucose in the absence or presence of $0.5 \mathrm{mM}$ metformin, respectively. The nuclear extracts were subjected to SDS-PAGE analysis and western blotting.
Total cell extract from cells ectopically expressing mouse PPAR $\alpha$ was used as a positive control. PPAR $\alpha$ protein levels reflected the changes in mRNA level in that $25 \mathrm{mM}$ glucose markedly reduced PPAR $\alpha$ protein, whereas metformin activation of AMPK counteracted glucose repression of PPAR $\alpha$ protein (Fig. 3A). To confirm that the glucose regulation of PPAR $\alpha$ protein is functionally significant, we investigated expression levels of the known PPAR $\alpha$ target genes ACO (Tugwood et al. 1992) and liver CPT-1 (Napal et al. 2005). Notably, expression of both target genes is reduced by glucose $(P<0 \cdot 05)$ and dose dependently restored by AMPK activation with metformin $(0 \cdot 25-1 \mathrm{mM})$ (Fig. 3B). Thus, the changes in PPAR $\alpha$ mRNA expression in response to glucose and AMPK activation are reflected by parallel changes in PPAR $\alpha$ protein level and expression of PPAR $\alpha$ target genes. 

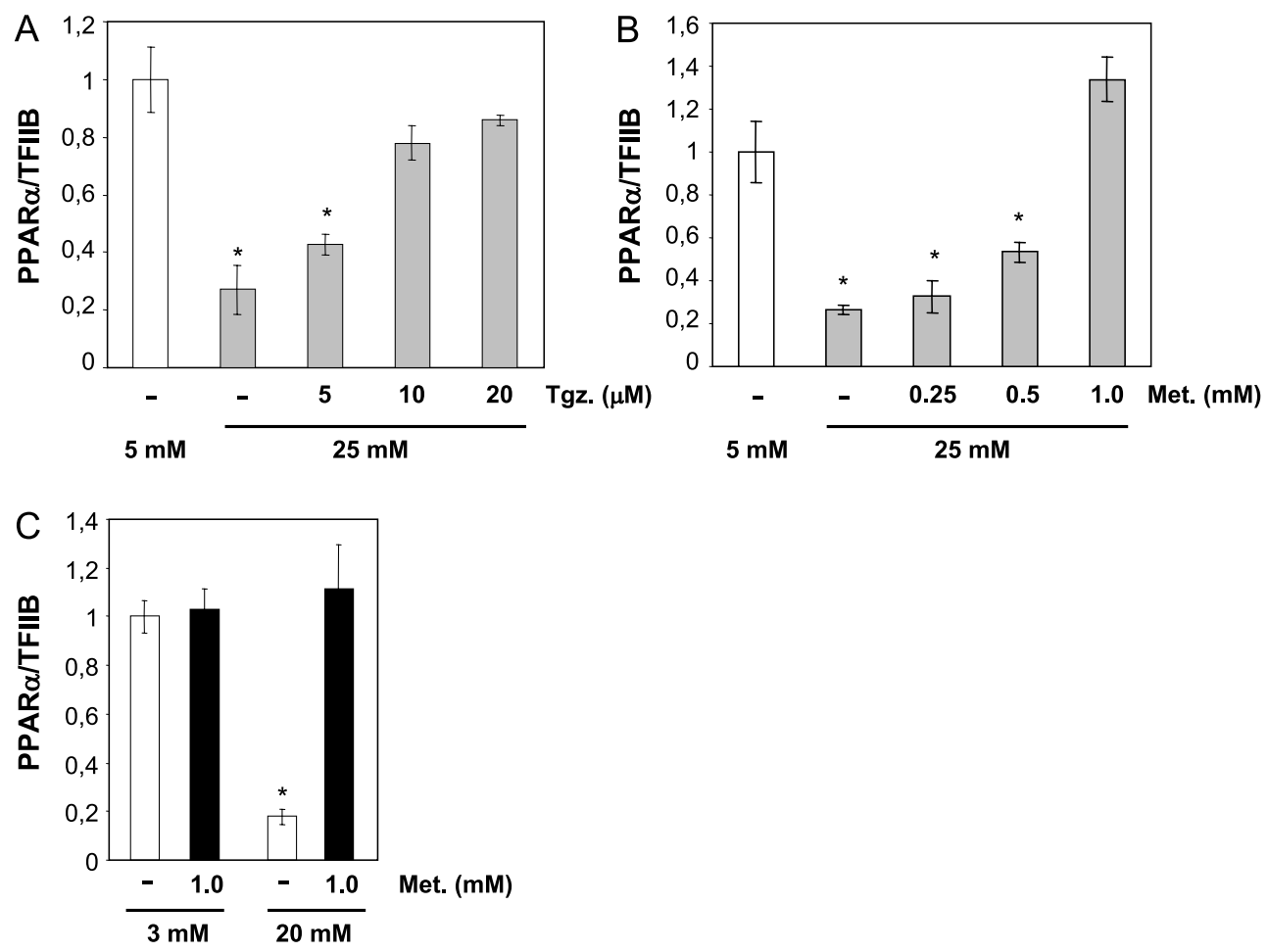

Figure 2 Pharmacological activators of AMPK interfere with glucose repression of the PPAR $\alpha$ gene in INS-1E cells and isolated rat islets. INS-1E cells were pre-cultured for $24 \mathrm{~h}$ in $5 \mathrm{mM}$ glucose medium before addition of glucose to $25 \mathrm{mM}$ with or without with troglitazone $(5,10$ and $20 \mu \mathrm{M})(\mathrm{A})$ or metformin $(0.25,0.5$ and $1 \mathrm{mM})(B)$. Cells were subsequently cultured for $24 \mathrm{~h}$ before total RNA was extracted. Freshly isolated rat islets were pre-cultured for $24 \mathrm{~h}$ in $3 \mathrm{mM}$ glucose medium before 24-h incubation at 3 or $20 \mathrm{mM}$ glucose in the presence or absence of metformin (1 mM) (C). Expression of PPAR $\alpha$ was quantified using real time PCR, normalized to TFIIB expression and presented relative to expression at $5 \mathrm{mM}$ glucose. RNA was harvested in duplicates, and range is indicated $\left({ }^{*}\right.$, significantly different from $5 \mathrm{mM}$ glucose $P<0.05)$. The presented results are representative of at least 3 independent experiments.

\section{Pharmacological activation of AMPK and inhibition of PP2A blocks glucose inhibition of $\beta$-cell AMPK activity}

The finding that glucose represses PPAR $\alpha$ expression in a manner counteracted by pharmacological activation of AMPK, points to a central role for AMPK in this response. To address this, AMPK activity was evaluated in INS-1E cells incubated for $0 \cdot 5-24 \mathrm{~h}$ at 5 and $25 \mathrm{mM}$ glucose alone or in the presence of troglitazone (5-20 $\mu \mathrm{M})$, metformin $(0.5 \mathrm{mM})$, or the PP2A inhibitor okadaic acid $(25 \mathrm{nM})$. AMPK activity was assessed by Western blotting and ECL detection of threonine-172 phosphorylation of the AMPK $\alpha$-subunit. In agreement with the acute glucose repression of PPAR $\alpha$ expression (Fig. 1A), $25 \mathrm{mM}$ glucose markedly reduced AMPK activity compared with $5 \mathrm{mM}$ glucose already after 30 min (Fig. 4A). This repression of AMPK activity by glucose persisted for at least $24 \mathrm{~h}$ (Fig. 4B and C). The TZD compound troglitazone dose-dependently restored
AMPK activity (Fig. 4B), as did metformin (Fig. 4C), without affecting the total protein level of AMPK $\alpha$ subunit. Glucose is known to activate PP2A. Interestingly, inhibition of PP2A by okadaic acid totally blocked the negative effect of glucose on AMPK activity (Fig. $4 \mathrm{C})$. These results confirm that AMPK activity is acutely repressed by glucose in the $\beta$-cell line INS-1E and show that this repression is counteracted by metformin and troglitazone as well as by inhibition of PP2A.

\section{Inhibition of PP2A blocks glucose repression of PPAR $\alpha$ expression}

To further investigate the role of PP2A in glucose action on $\beta$-cell PPAR $\alpha$ expression, PP2A activity was chemically inhibited in INS-1E cells stimulated with $25 \mathrm{mM}$ glucose and PPAR $\alpha$ mRNA levels were analyzed by real time PCR. Resembling the stimulating effect on AMPK-activity, chemical inhibition of PP2A using the specific inhibitor okadaic acid (12.5 or $25 \mathrm{nM})$ 
A
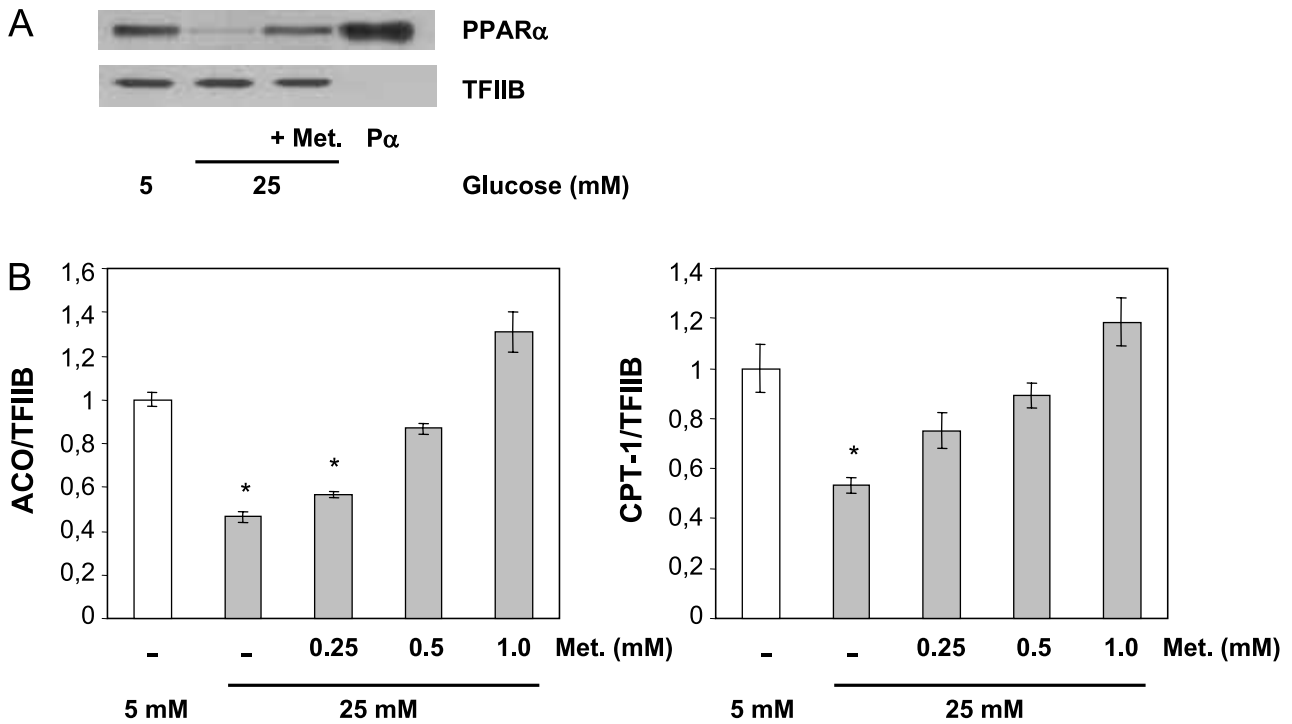

Figure 3 Pharmacological activation of AMPK interferes with glucose repression of PPAR $\alpha$ protein and target gene expression. INS-1E cells were pre-cultured for $24 \mathrm{~h}$ in $5 \mathrm{mM}$ glucose medium before addition of glucose to $25 \mathrm{mM}$ with or without with metformin (protein: $0.5 \mathrm{mM}$, RNA: $0.25,0.5$ or $1 \mathrm{mM}$ ). Cells were subsequently cultured for $24 \mathrm{~h}$ before nuclear proteins and RNA was extracted. (A) Proteins were separated by SDS-PAGE and levels of PPAR $\alpha$ and TFIIB visualized by immunoblotting. Extract from cells ectopically expressing mPPAR $\alpha$ was used as positive control $(\mathrm{P} \alpha)$. (B) The expression levels of ACO and CPT-1 were quantified by real time PCR, normalized to TFIIB expression and presented relative to expression at $5 \mathrm{mM}$ glucose. RNA was harvested in duplicates, and range is indicated ${ }^{*}$, significantly different from $5 \mathrm{mM}$ glucose $\left.P<0.05\right)$. The presented results are representative of at least 3 independent experiments.

dose-dependently restored PPAR $\alpha$ levels (Fig. 5A, $P<0 \cdot 05)$. This was confirmed by adenoviral transduction (titer $40 \mathrm{pfu} / \mathrm{cell}$ ) of INS-1E cells with SV40 small-t antigen-a protein known to form a stable complex with PP2A and inhibit it's catalytic activity (Yang et al. 1991). Similarly to okadaic acid, SV40 small-t antigen blunted the glucose effect on PPAR $\alpha$ expression (Fig. 5B, $P<0 \cdot 05)$. A mutated form of SV40 small-t antigen (C103S) expressed to the same level but unable to interact with PP2A (Porras et al. 1996) did not affect PPAR $\alpha$ expression nor did Ad-CMV (G). These results indicate that glucose activation of PP2A or PP2A-like kinases is necessary for glucose-induced repression of PPAR $\alpha$ gene expression.

\section{Specific knock-down of the catalytic AMPK $\alpha 2-s u b u n i t$ mimics glucose-induced PPAR $\alpha$ repression}

To confirm the role of AMPK activity in maintenance of PPAR $\alpha$ gene expression under low glucose conditions, we generated adenoviral vectors expressing shRNA for specific knock-down of the catalytic subunits $\alpha 1$ and $\alpha 2$. INS-1E cells were transduced with these adenoviral shRNA constructs targeting AMPK $\alpha 1, \alpha 2$, or a combination of both, respectively, for $72 \mathrm{~h}$ in $5 \mathrm{mM}$ glucose medium. Control cells were transduced with an empty adenoviral shRNA-vector $(\mathrm{C})$. Total RNA and protein was extracted and AMPK $\alpha$ mRNA (Fig. 6A) and protein levels (Fig. 6B) were investigated. Specific knock-down of the AMPK $\alpha 1$ and $\alpha 2$ genes was confirmed by quantitative real time PCR $(50 \%$ and $60 \%$ mRNA reduction respectively, $P<0 \cdot 05)$. Also AMPK $\alpha$ protein level was reduced by knock-down as assessed by western blotting and ECL-detection of total level of AMPK $\alpha$ subunit. Whereas knock-down of AMPK $\alpha 1$ did not affect PPAR $\alpha$ expression level, AMPKa2 knockdown reduced the PPAR $\alpha$ mRNA level by $\sim 50 \%$ (Fig. $6 \mathrm{C}, P<0.05)$. These results show that the activity of AMPK $\alpha 2$, but not that of AMPK $\alpha 1$, is important for maintenance of PPAR $\alpha$ gene expression.

\section{Discussion}

During the last years, our knowledge about the family of AMPKs has expanded dramatically. Once a glucose sensor in budding yeast (Celenza \& Carlson 1986) the AMPK is now considered a central fuel gauge upholding mammalian energy homeostasis and controlling fuel selection in various metabolically important tissues (reviewed in Kahn et al. 2005). Metabolic signals such as 


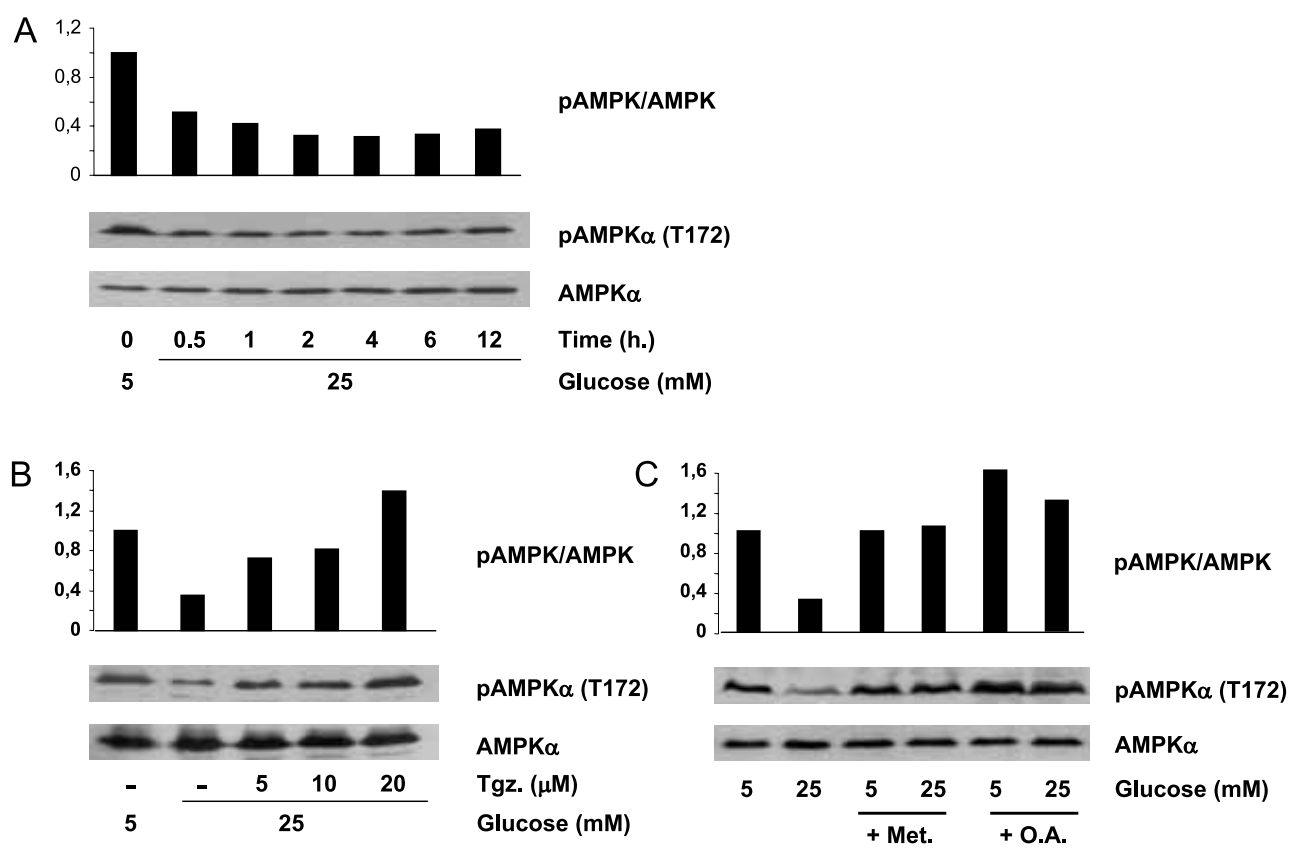

Figure 4 AMPK activity is repressed by glucose but restored by troglitazone, metformin and PP2A inhibition. (A) and (B) INS-1E cells were pre-cultured for $24 \mathrm{~h}$ in $5 \mathrm{mM}$ glucose medium before addition of glucose to $25 \mathrm{mM}$ with or without with troglitazone $(5,10,20 \mu \mathrm{M})$. (C) INS-1E cells pre-cultured at $5 \mathrm{mM}$ glucose were treated with metformin $(0.5 \mathrm{mM})$ or okadaic acid $(25 \mathrm{nM})$ at $5 \mathrm{mM}$ or $25 \mathrm{mM}$ glucose, respectively. Cells were harvested and whole cell extracts subsequently prepared at the indicated time points A or after $24 \mathrm{~h}$ incubation B and C. Proteins were separated by SDS-PAGE and levels of phosphoAMPK $\alpha$ (Thr172) and AMPK $\alpha$ visualized by immunoblotting and densitometric quantification. The presented results are representative of at least 3 independent experiments.

adipokines (Minokoshi et al. 2002, Yamauchi et al. 2002, Banerjee et al. 2004), hormones (Minokoshi et al. 2004) and nutrients (da Silva et al. 2000, Leclerc \& Rutter
2004, Koo et al. 2005) are integrated by the AMPK centrally and peripherally resulting in increased food intake, reduced hepatic glucose output and a general shift
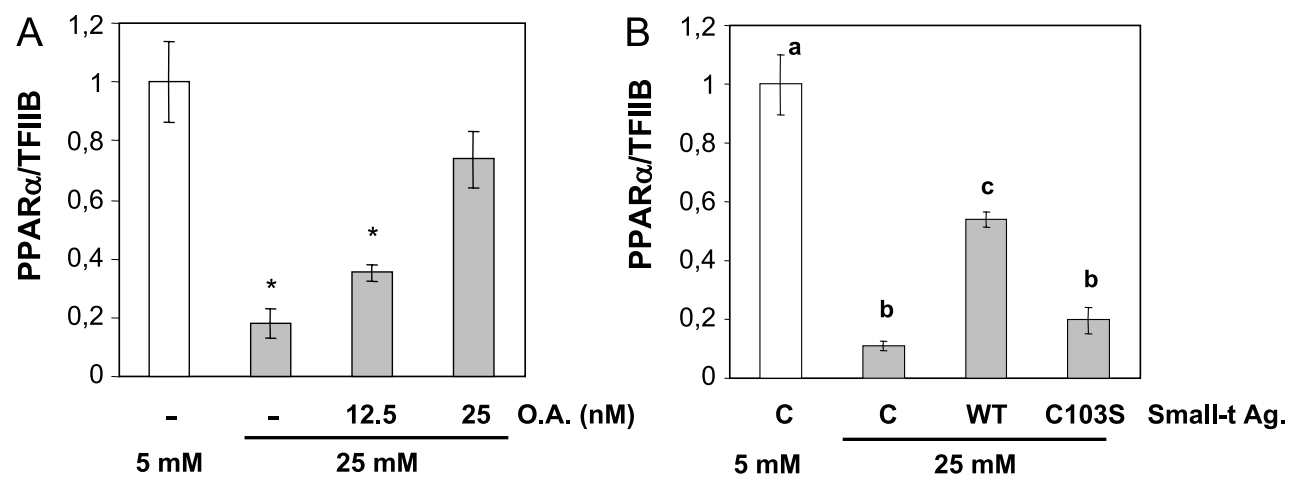

Figure 5 Inhibition of PP2A interferes with glucose repression of PPAR $\alpha$ gene expression. (A) INS-1E cells were pre-cultured for $24 \mathrm{~h}$ at $5 \mathrm{mM}$ glucose. The glucose concentration was increased to $25 \mathrm{mM}$, DMSO or okadaic acid $(12.5$ or $25 \mathrm{nM})$ was added, and cells were cultured for $24 \mathrm{~h}$ before harvesting of RNA. (B) Cells were adenovirally transduced with SV40 small-t-antigen wt or mutant (C103S) or Ad-CMV as control (C) at $5 \mathrm{mM}$ glucose. After $24 \mathrm{~h}$, the glucose concentration was increased to $25 \mathrm{mM}$ and cells were subsequently cultured for $24 \mathrm{~h}$ before total RNA was extracted. Expression of PPAR $\alpha$ was quantified by real time PCR, normalized to TFIIB expression and presented relative to expression at $5 \mathrm{mM}$ glucose. RNA was harvested in duplicates, and range is indicated. Means not sharing same superscript differ significantly $(P<0.05)$. The presented results are representative of at least 3 independent experiments. 

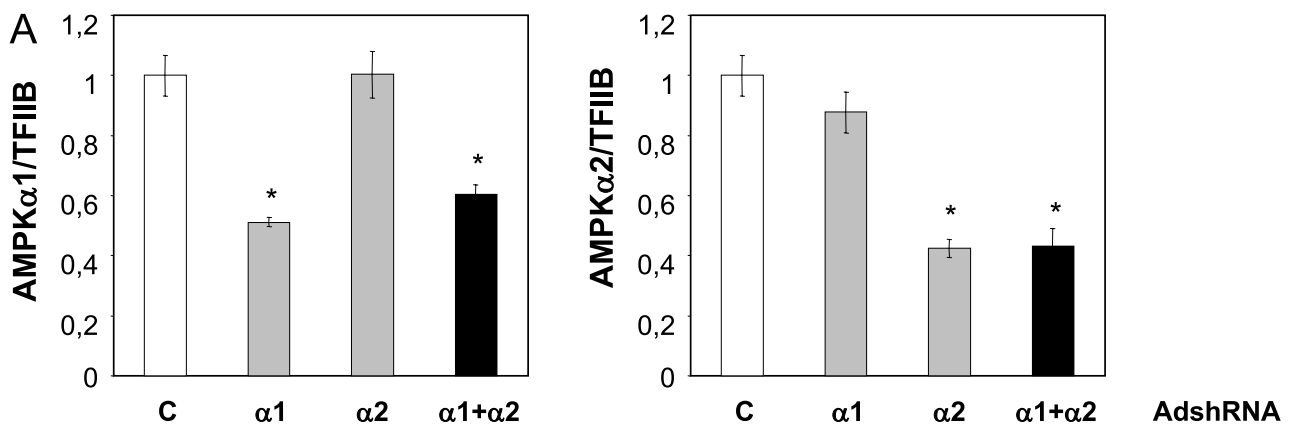

B

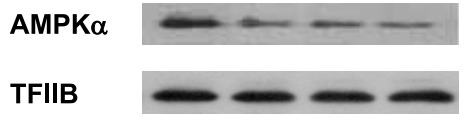

$\begin{array}{lllll}\text { AdshRNA } & C & \alpha 1 & \alpha 2 & \alpha 1+\alpha 2\end{array}$

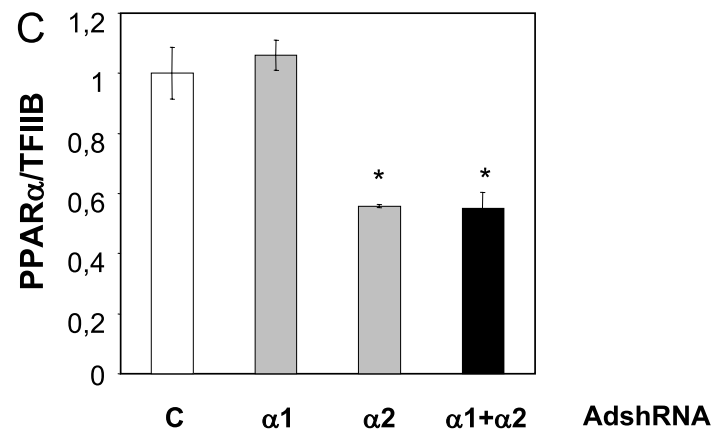

Figure 6 Specific knock-down of AMPK $\alpha 2$ represses PPAR $\alpha$ expression. INS-1E cells were transduced with a control virus AdshEmpty (C), adenoviral shRNA vectors AdshAMPK $\alpha 1$,

AdshAMPK $\alpha 2$ or both and cultured for $72 \mathrm{~h}$ at $5 \mathrm{mM}$ glucose. Total mRNA and protein was extracted. (A) Relative knock-down of either AMPK $\alpha$ subunit $\alpha 1$ and $\alpha 2$ was quantified by real time PCR and normalized to TFIIB expression. (B) Knock-down of AMPK $\alpha$ protein was confirmed by western blotting and ECL. (C) PPAR $\alpha$ expression was quantified by real time PCR and normalized to TFIIB expression. RNA was harvested in duplicates, and range is indicated ${ }^{*}$, significantly different from control $P<0.05)$. The presented results are representative of at least 3 independent experiments.

from energy expenditure to energy production. Also pharmacologically, the AMPK is of substantial interest. Anti-diabetic compounds such as metformin and rosiglitazone of the biguanide and thiazolidinedione classes, respectively, have been shown to activate AMPK (Zhou et al. 2001, Fryer et al. 2002). Metformin was recently reported to activate hepatic AMPK through activation of the upstream AMPK-kinase LKB1 (Shaw et al. 2005).

Here we describe a novel role for AMPK in the pancreatic $\beta$-cell. In keeping with AMPK stimulation of fatty acid oxidation in various tissues, we show that AMPK is important for the maintenance of PPAR $\alpha$ gene expression in INS-1E cells and primary $\beta$-cells. Furthermore, we provide evidence that AMPK inactivation is a key event in glucose-induced repression of PPAR $\alpha$ expression. While acutely decreasing AMPK activity, glucose represses PPAR $\alpha$ expression independently of $\beta$-cell excitation and insulin secretion in both the INS-1E $\beta$-cell line and isolated rat islets. Importantly, repression of PPAR $\alpha$ gene expression is reflected at PPAR $\alpha$ protein level together with expression levels of the known PPAR $\alpha$ target genes ACO and CPT-1 in a manner completely reversed by pharmacological activation of AMPK. Specific knock- down of AMPK $\alpha 2$, but not AMPK $\alpha 1$, reduces PPAR $\alpha$ expression even at a low glucose level, suggesting that inactivation of AMPK $\alpha 2$ by glucose is upstream to PPAR $\alpha$ gene repression. This is in agreement with our finding that metformin did not have any effect on islet PPAR $\alpha$ expression under non-repressive low glucose conditions. To further explore the underlying mechanism, we chemically inhibited phosphatases known to be activated by glucose and found that inhibition of PP2A using okadaic acid attenuated glucose-induced inactivation of AMPK as well as repression of PPAR $\alpha$ expression. This was confirmed by specific SV40 small-t antigen mediated inhibition of PP2A activity. SV40 small-t antigen forms a stable complex with the PP2A A-subunit replacing the regulatory B-subunit and inhibiting PP2A activity (Yang et al. 1991). The relative contribution of ATP generation from glucose oxidation to AMPK inactivation was not assessed in our experiments. Notably however, PP2A inhibition with okadaic acid entirely restored AMPK $\alpha$ phosphorylation level at $25 \mathrm{mM}$ glucose (Fig. 4C), suggesting that glucose could suppress AMPK $\alpha$ activity by activating PP2A rather than through an increase in the ATP/AMP ratio. A model where glucose activates PP2A leading to AMPK 


\section{Glucose}

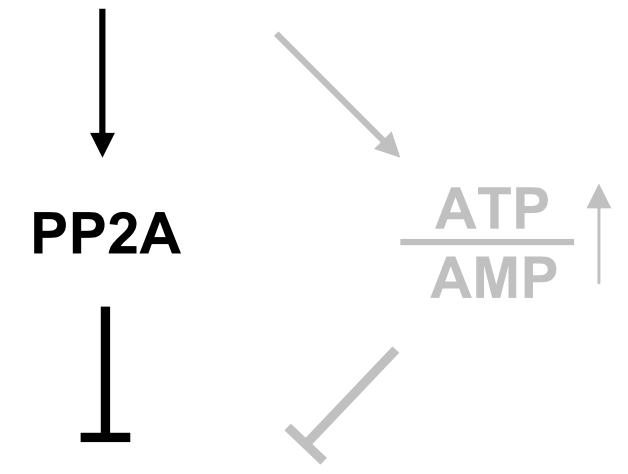

AMPK

PPAR $\alpha$

Figure 7 Proposed model for glucose-induced repression of PPAR $\alpha$ gene expression in pancreatic $\beta$-cells. The effect of the potential glucose-stimulated increase in the ATP/AMP ratio on AMPK activity was not addressed but added for completion.

inactivation and PPAR $\alpha$ repression (outlined in Fig. 7) is attractive as homologous pathways controlling energy substrate selection are known from yeast (Jiang \& Carlson 1996). Glucose has previously been shown to inactivate AMPK in $\beta$-cells (Salt et al. 1998b, da Silva et al. 2000), and recent findings that glucose and PP2A can disrupt mammalian AMPK subunit association (Gimeno-Alcaniz \& Sanz 2003) support the depicted model.

AMPK activity is known to counteract glucosestimulated gene expression through inhibition of ChREBP (Kawaguchi et al. 2002), whereas possible involvement of AMPK in repression of mammalian genes by glucose has not previously been described. However, treatment of islets from hyperglycemic Zucker diabetic fatty (ZDF) rats with leptin resulted in increased fatty acid oxidation, islet delipidation and functional restoration (Zhou et al. 1997, 1998). Strikingly, the lipopenic effect of leptin was associated with an increase in expression of both PPAR $\alpha$ and PPAR $\alpha$ target genes. Leptin is known to promote fatty acid oxidation in various tissues but only in skeletal muscle this has been shown to involve AMPK activation (Minokoshi et al. 2002). Also troglitazone, here used to activate AMPK, has a similar potential to counteract glucolipotoxicity in isolated ZDF rat islets through delipidation (Shimabukuro et al. 1998a, Higa et al. 1999). Both observations are in keeping with our data showing that activation of AMPK leads to increased PPAR $\alpha$ expression. Of note, PPAR $\gamma$ is not expressed at significant levels in INS-1E cells (data not shown). Therefore it is unlikely that troglitazone, which is also a PPAR $\gamma$ agonist, affects PPAR $\alpha$ expression through activation of PPAR $\gamma$ in the present study.

Our finding that specific knock-down of the $\alpha 2$ but not the $\alpha 1$ subunit of AMPK in the $\beta$-cell suppresses PPAR $\alpha$ expression indicates a functional specialization of the two catalytic isoforms. This was previously addressed by specific $\alpha 1$ and $\alpha 2$ knock-out models (Viollet et al. 2003). Whereas AMPK $\alpha 1^{-/-}$mice did not display any phenotypic abnormalities, AMPK $\alpha 2^{-/-}$mice were highly glucose intolerant with impaired GSIS. The $\beta$-cell dysfunction observed in vivo was not found in isolated $\mathrm{AMPK} \alpha 2^{-/-}$islets, suggesting that GSIS impairment was either not a primary defect, or that $\beta$-cell AMPK $\alpha 2$ depletion is critical only in the in vivo AMPK $\alpha 2^{-/-}$environment with chronically increased levels of fatty acids and catecholamines. Other studies functionally comparing AMPK $\alpha 1$ and $\alpha 2$ revealed that the $\alpha 1$ subunit is cytoplasmatic, whereas AMPK $\alpha 2$ is also found in the nucleus of $\beta$-cell lines (Salt et al. 1998a, da Silva et al. 2000). AMPKal is hence likely to phosphorylate cytoplasmatic substrates, whereas AMPKa2 may be involved in the conversion of metabolic signals into transcriptional regulation. This model is supported by our data showing that AMPK $\alpha 2$, but not AMPK $\alpha 1$, is involved in the maintenance of PPARa expression. In addition, our RNAi based approach supports previous studies in MIN6 insulinoma cells where inactivation of AMPK $\alpha 2$ by antibody injection at low glucose mimicked glucose induction of the L-PK (da Silva et al. 2000). Of note, a similar approach in primary hepatocytes, where a dominant negative AMPKa subunit was used to inactivate endogenous AMPK at low glucose, showed no effect on L-PK expression (Woods et al. 2000). Whether this discrepancy reveals a general difference between $\beta$-cells and hepatocytes or simply reflects different experimental conditions is still to be resolved. In a recent study, ectopic expression of a constitutive active AMPK $\alpha$ subunit in rat islets did not affect PPAR $\alpha$ expression (Diraison et al. 2004). However, as the authors note, the experiments were performed at $3 \mathrm{mM}$ glucose, reducing the impact of ectopic AMPK $\alpha$ expression. This would be in agreement with our present data (Fig. 2C). Furthermore, substrate recognition of a deregulated catalytic AMPK $\alpha$ subunit expressed alone could be compromised by the relative lack of regulatory subunits.

In conclusion, we describe here for the first time the involvement of AMPK in repression of gene expression by glucose. We find that repression of PPAR $\alpha$ gene expression by glucose in INS-1E insulinoma cells involves activation of PP2A and inactivation of AMPK. 
This mechanism is likely to apply also to primary $\beta$-cells, since AMPK activation totally abolishes glucose repression of the PPAR $\alpha$ gene in isolated rat islets. Our result that AMPK $\alpha 2$ but not AMPK $\alpha 1$ is necessary for maintenance of PPAR $\alpha$ gene expression suggest that glucose acts primarily by inactivation of AMPK $\alpha 2$. Hence, acute inactivation of the AMPK $\alpha 2$ appears to be a critical step in both induction and repression of genes by glucose in pancreatic $\beta$-cells. PPAR $\alpha$ is a known key regulator of fatty acid oxidation, and PPAR $\alpha$ expression in the $\beta$-cell is important for $\beta$-cell function (Zhou et al. 1998, Ravnskjaer et al. 2005). Thus, the ability of AMPK to increase PPAR $\alpha$ expression under hyperglycemic conditions indicates that pharmacological activators of AMPK may exert direct beneficial effects on $\beta$-cell lipid partitioning and contribute to $\beta$-cell protection.

\section{Acknowledgements}

The authors are grateful to Claes Wollheim for supplying the INS-1E cell line, Kathleen Rundell for adenoviral SV40 small-t antigen, René Bernards for the pSuper vector and Novo Nordisk for troglitazone.

\section{Funding}

This work was supported by grants from the Danish Health Science Research Council and the Danish Diabetes Foundation. M B is supported by a Novo Nordisk scholarship. The authors declare that there is no conflict of interest that would prejudice the impartiality of this scientific work.

\section{References}

Banerjee RR, Rangwala SM, Shapiro JS, Rich AS, Rhoades B, Qi Y, Wang J, Rajala MW, Pocai A, Scherer PE, Steppan CM, Ahima RS, Obici S, Rossetti L \& Lazar MA 2004 Regulation of fasted blood glucose by resistin. Science 303 1195-1198.

Brummelkamp TR, Bernards R \& Agami R 2002 A system for stable expression of short interfering RNAs in mammalian cells. Science 296 550-553.

Celenza JL \& Carlson M 1986 A yeast gene that is essential for release from glucose repression encodes a protein kinase. Science $2331175-1180$.

Chomczynski P \& Sacchi N 1987 Single-step method of RNA isolation by acid guanidinium thiocyanate-phenol-chloroform extraction. Analytical Biochemistry 162 156-159.

da Silva, Leclerc I, Salt IP, Doiron B, Hardie DG, Kahn A \& Rutter GA 2000 Role of AMP-activated protein kinase in the regulation by glucose of islet beta cell gene expression. PNAS 97 4023-4028.

Diraison F, Motakis E, Parton LE, Nason GP, Leclerc I \& Rutter GA 2004 Impact of adenoviral transduction with SREBP1c or AMPK on pancreatic islet gene expression profile: analysis with oligonucleotide microarrays. Diabetes $\mathbf{5 3}$ S84-S91.

El Assaad W, Buteau J, Peyot ML, Nolan C, Roduit R, Hardy S, Joly E, Dbaibo G, Rosenberg L \& Prentki M 2003 Saturated fatty acids synergize with elevated glucose to cause pancreatic beta-cell death. Endocrinology 144 4154-4163.

Fryer LG, Parbu-Patel A \& Carling D 2002 The Anti-diabetic drugs rosiglitazone and metformin stimulate AMP-activated protein kinase through distinct signaling pathways. Fournal of Biological Chemistry $27725226-25232$.

Gimeno-Alcaniz JV \& Sanz P 2003 Glucose and type 2A protein phosphatase regulate the interaction between catalytic and regulatory subunits of AMP-activated protein kinase. Fournal of Molecular Biology 333 201-209.

Gremlich S, Nolan C, Roduit R, Burcelin R, Peyot ML, Delghingaro-Augusto V, Desvergne B, Michalik L, Prentki M \& Wahli W 2004 Pancreatic islet adaptation to fasting is dependent on ppar\{alpha\} transcriptional up-regulation of fatty acid oxidation. Endocrinology 146 375-382.

Guerre-Millo M, Rouault C, Poulain P, Andre J, Poitout V, Peters JM, Gonzalez FJ, Fruchart JC, Reach G \& Staels B 2001 PPAR-alpha-null mice are protected from high-fat diet-induced insulin resistance. Diabetes $\mathbf{5 0} 2809-2814$.

Higa M, Zhou YT, Ravazzola M, Baetens D, Orci L \& Unger RH 1999 Troglitazone prevents mitochondrial alterations, beta cell destruction, and diabetes in obese prediabetic rats. PNAS 96 11513-11518.

Itoh Y, Kawamata Y, Harada M, Kobayashi M, Fujii R, Fukusumi S, Ogi K, Hosoya M, Tanaka Y, Uejima H, Tanaka H, Maruyama M, Satoh R, Okubo S, Kizawa H, Komatsu H, Matsumura F, Noguchi Y, Shinohara T, Hinuma S, Fujisawa Y \& Fujino M 2003 Free fatty acids regulate insulin secretion from pancreatic beta cells through GPR40. Nature 422 173-176.

Jiang R \& Carlson M 1996 Glucose regulates protein interactions within the yeast SNF1 protein kinase complex. Genes Development $103105-3115$.

Kahn BB, Alquier T, Carling D \& Hardie DG 2005 AMP-activated protein kinase: ancient energy gauge provides clues to modern understanding of metabolism. Cell Metabolism 1 15-25.

Kawaguchi T, Osatomi K, Yamashita H, Kabashima T \& Uyeda K 2002 Mechanism for fatty acid 'sparing' effect on glucose-induced transcription: regulation of carbohydrate-responsive elementbinding protein by AMP-activated protein kinase. Fournal of Biological Chemistry 277 3829-3835.

Koo SH, Flechner L, Qi L, Zhang X, Screaton RA, Jeffries S, Hedrick S, Xu W, Boussouar F, Brindle P, Takemori H \& Montminy M 2005 The CREB coactivator TORC2 is a key regulator of fasting glucose metabolism. Nature 437 1109-1111.

Laybutt DR, Sharma A, Sgroi DC, Gaudet J, Bonner-Weir S \& Weir GC 2002 Genetic regulation of metabolic pathways in beta-cells disrupted by hyperglycemia. Fournal of Biological Chemistry 277 10912-10921.

Leclerc I \& Rutter GA 2004 AMP-activated protein kinase: a new beta-cell glucose sensor?: Regulation by amino acids and calcium ions. Diabetes 53 S67-S74.

Leclerc I, Woltersdorf WW, da S, X, Rowe RL, Cross SE, Korbutt GS, Rajotte RV, Smith R \& Rutter GA 2004 Metformin, but not leptin, regulates AMP-activated protein kinase in pancreatic islets: impact on glucose-stimulated insulin secretion. American fournal of Physiology, Endocrinology and Metabolism 286 E1023-E1031.

Maedler K, Spinas GA, Dyntar D, Moritz W, Kaiser N \& Donath MY 2001 Distinct effects of saturated and monounsaturated fatty acids on beta-cell turnover and function. Diabetes $\mathbf{5 0} 69-76$.

Merglen A, Theander S, Rubi B, Chaffard G, Wollheim CB \& Maechler P 2004 Glucose sensitivity and metabolism-secretion coupling studied during two-year continuous culture in INS-1E insulinoma cells. Endocrinology 145 667-678.

Minokoshi Y, Kim YB, Peroni OD, Fryer LG, Muller C, Carling D \& Kahn BB 2002 Leptin stimulates fatty-acid oxidation by activating AMP-activated protein kinase. Nature 415 339-343.

Minokoshi Y, Alquier T, Furukawa N, Kim YB, Lee A, Xue B, Mu J, Foufelle F, Ferre P, Birnbaum MJ, Stuck BJ \& Kahn BB 2004 
AMP-kinase regulates food intake by responding to hormonal and nutrient signals in the hypothalamus. Nature $\mathbf{4 2 8} 569-574$.

Napal L, Marrero PF \& Haro D 2005 An intronic peroxisome proliferator-activated receptor-binding sequence mediates fatty acid induction of the human carnitine palmitoyltransferase 1A. Fournal of Molecular Biology 354 751-759.

Porras A, Bennett J, Howe A, Tokos K, Bouck N, Henglein B, Sathyamangalam S, Thimmapaya B \& Rundell K 1996 A novel simian virus 40 early-region domain mediates transactivation of the cyclin A promoter by small-t antigen and is required for transformation in small-t antigen-dependent assays. Fournal of Virology 70 6902-6908.

Ravnskjaer K, Boergesen M, Rubi B, Larsen JK, Nielsen T, Fridriksson J, Maechler P \& Mandrup S 2005 Peroxisome proliferator-activated receptor alpha (PPARalpha) potentiates, whereas PPARgamma attenuates, glucose-stimulated insulin secretion in pancreatic beta-cells. Endocrinology 146 3266-3276.

Roche E, Farfari S, Witters LA, Assimacopoulos-Jeannet F, Thumelin S, Brun T, Corkey BE, Saha AK \& Prentki M 1998 Long-term exposure of beta-INS cells to high glucose concentrations increases anaplerosis, lipogenesis, and lipogenic gene expression. Diabetes 47 1086-1094.

Roduit R, Morin J, Masse F, Segall L, Roche E, Newgard CB, Assimacopoulos-Jeannet F \& Prentki M 2000 Glucose downregulates the expression of the peroxisome proliferator-activated receptor-alpha gene in the pancreatic beta -cell. Fournal of Biological Chemistry 275 35799-35806.

Roduit R, Nolan C, Alarcon C, Moore P, Barbeau A, Delghingaro-Augusto V, Przybykowski E, Morin J, Masse F, Massie B, Ruderman N, Rhodes C, Poitout V \& Prentki M 2004 A role for the malonyl-CoA/long-chain acyl-CoA pathway of lipid signaling in the regulation of insulin secretion in response to both fuel and nonfuel stimuli. Diabetes 53 1007-1019.

Salt I, Celler JW, Hawley SA, Prescott A, Woods A, Carling D \& Hardie DG 1998 a AMP-activated protein kinase: greater AMP dependence, and preferential nuclear localization, of complexes containing the alpha2 isoform. Biochemical fournal 334 177-187.

Salt IP, Johnson G, Ashcroft SJ \& Hardie DG 1998b AMP-activated protein kinase is activated by low glucose in cell lines derived from pancreatic beta cells, and may regulate insulin release. Biochemical fournal 335 533-539.

Samari HR, Moller MT, Holden L, Asmyhr T \& Seglen PO 2005 Stimulation of hepatocytic AMP-activated protein kinase by okadaic acid and other autophagy-suppressive toxins. Biochemical fournal 386 237-244.

Shaw RJ, Lamia KA, Vasquez D, Koo SH, Bardeesy N, Depinho RA, Montminy M \& Cantley LC 2005 The Kinase LKB1 Mediates Glucose Homeostasis in Liver and Therapeutic Effects of Metformin. Science 310 1642-1646.

Shimabukuro M, Zhou YT, Lee Y \& Unger RH 1998a Troglitazone lowers islet fat and restores beta cell function of Zucker diabetic fatty rats. Fournal of Biological Chemistry 273 3547-3550.

Shimabukuro M, Zhou YT, Levi M \& Unger RH $1998 b$ Fatty acid-induced beta cell apoptosis: a link between obesity and diabetes. PNAS 95 2498-2502.

Stein DT, Esser V, Stevenson BE, Lane KE, Whiteside JH, Daniels MB, Chen S \& McGarry JD 1996 Essentiality of circulating fatty acids for glucose-stimulated insulin secretion in the fasted rat. Journal of Clinical Investigation 97 2728-2735.
Susini S, Roche E, Prentki M \& Schlegel W 1998 Glucose and glucoincretin peptides synergize to induce c-fos, c-jun, junB, zif-268, and nur-77 gene expression in pancreatic beta(INS-1) cells. FASEB fournal 12 1173-1182.

Tordjman K, Standley KN, Bernal-Mizrachi C, Leone TG, Coleman T, Kelly DP \& Semenkovich CF 2002 PPARalpha suppresses insulin secretion and induces UCP2 in insulinoma cells. Journal of Lipid Research 43 936-943.

Tugwood JD, Issemann I, Anderson RG, Bundell KR, McPheat WL \& Green S 1992 The mouse peroxisome proliferator activated receptor recognizes a response element in the $5^{\prime}$ flanking sequence of the rat acyl CoA oxidase gene. EMBO fournal 11 433-439.

Viollet B, Andreelli F, Jorgensen SB, Perrin C, Geloen A, Flamez D, Mu J, Lenzner C, Baud O, Bennoun M, Gomas E, Nicolas G, Wojtaszewski JF, Kahn A, Carling D, Schuit FC, Birnbaum MJ, Richter EA, Burcelin R \& Vaulont S 2003 The AMP-activated protein kinase alpha2 catalytic subunit controls whole-body insulin sensitivity. Fournal of Clinical Investigations 111 91-98.

Wang H \& Wollheim CB 2002 ChREBP rather than USF2 regulates glucose stimulation of endogenous L-pyruvate kinase expression in insulin-secreting cells. Fournal of Biological Chemistry 277 32746-32752.

Woods A, Azzout-Marniche D, Foretz M, Stein SC, Lemarchand P, Ferre P, Foufelle F \& Carling D 2000 Characterization of the role of AMP-activated protein kinase in the regulation of glucoseactivated gene expression using constitutively active and dominant negative forms of the kinase. Molecular and Cellular Biology $206704-6711$.

Yamauchi T, Kamon J, Minokoshi Y, Ito Y, Waki H, Uchida S, Yamashita S, Noda M, Kita S, Ueki K, Eto K, Akanuma Y, Froguel P, Foufelle F, Ferre P, Carling D, Kimura S, Nagai R, Kahn BB \& Kadowaki T 2002 Adiponectin stimulates glucose utilization and fatty-acid oxidation by activating AMP-activated protein kinase. Nature Medicine 8 1288-1295.

Yang SI, Lickteig RL, Estes R, Rundell K, Walter G \& Mumby MC 1991 Control of protein phosphatase 2A by simian virus 40 small-t antigen. Molecular and Cellular Biology 11 1988-1995.

Zhang S \& Kim KH 1995 Glucose activation of acetyl-CoA carboxylase in association with insulin secretion in a pancreatic beta-cell line. Fournal of Endocrinology 147 33-41.

Zhou YT, Shimabukuro M, Koyama K, Lee Y, Wang MY, Trieu F, Newgard CB \& Unger RH 1997 Induction by leptin of uncoupling protein-2 and enzymes of fatty acid oxidation. PNAS 94 6386-6390.

Zhou YT, Shimabukuro M, Wang MY, Lee Y, Higa M, Milburn JL, Newgard CB \& Unger RH 1998 Role of peroxisome proliferator-activated receptor alpha in disease of pancreatic beta cells. PNAS 95 8898-8903.

Zhou G, Myers R, Li Y, Chen Y, Shen X, Fenyk-Melody J, Wu M, Ventre J, Doebber T, Fujii N, Musi N, Hirshman MF, Goodyear LJ \& Moller DE 2001 Role of AMP-activated protein kinase in mechanism of metformin action. Fournal of Clinical Investigation $1081167-1174$.

Received in final form 14 December 2005

Accepted 18 January 2006

Made available online as an Accepted Preprint 19 January 2006 